\title{
Can COVID-19 pandemic boost the epidemic of neurodegenerative diseases?
}

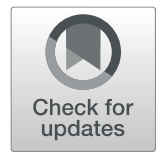

\author{
Alexei Verkhratsky ${ }^{1,2^{*}}$ (D), Qing Li $i^{3}$, Sonia Melino ${ }^{4}$ (D) Gerry Melino ${ }^{4}$ (i) and Yufang Shi ${ }^{3,5^{*}}$ (D)
}

\begin{abstract}
The pandemic of Coronavirus Disease 2019 (COVID-19) presents the world with the medical challenge associated with multifactorial nature of this pathology. Indeed COVID-19 affects several organs and systems and presents diversified clinical picture. COVID-19 affects the brain in many ways including direct infection of neural cells with SARS-CoV-2, severe systemic inflammation which floods the brain with pro-inflammatory agents thus damaging nervous cells, global brain ischaemia linked to a respiratory failure, thromboembolic strokes related to increased intravascular clotting and severe psychological stress. Often the COVID-19 is manifested by neurological and neuropsychiatric symptoms that include dizziness, disturbed sleep, cognitive deficits, delirium, hallucinations and depression. All these indicate the damage to the nervous tissue which may substantially increase the incidence of neurodegenerative diseases and promote dementia.
\end{abstract}

Keywords: SARS-Cov-2, COVID-19, Systemic inflammation, Brain, Cognitive deficits, neurodegeneration

The second wave of COVID-19 pandemic engulfs the world with number of people infected with SARS-Cov-2 raised over 56 millions with virus claiming more than 1.4 millions of lives [1-4]. These numbers are au pare with another epidemic that slowly but certainly swamps the world - the epidemic (as it was defined by Robert Katzman in 1976 [5]) of neurodegenerative diseases, which propagate through our rapidly ageing population. Along with the rapid changes in living environment and lifestyles, the number of people suffering from neurodegenerative disorders, that include vascular dementia, Alzheimer's and Parkinson disease, frontotemporal dementia, various tauopathies and so forth are estimated at 60-70 millions worldwide and these numbers are rising with projection of doubling within next 20 years [6-8].

\footnotetext{
* Correspondence: Alexej.Verkhratsky@manchester.ac.uk;

shiyufang2@gmail.com; yufangshi@sibs.ac.cn

${ }^{1}$ Faculty of Biology, Medicine and Health, The University of Manchester, Manchester M13 9PT, UK

${ }^{3}$ CAS Key Laboratory of Tissue Microenvironment and Tumor, Shanghai Institute of Nutrition and Health, Chinese Academy of Sciences, 320 Yueyang Road, Shanghai 200031, China

Full list of author information is available at the end of the article
}

The numbers of death from $\mathrm{AD}$ alone increased by $146 \%$ between year 2000 and year 2018 [9]. Although the main battlefield of neurodegenerative disorders is the brain, these diseases are title connected with the overall body state, with the onset and course of neurodegenerative diseases being substantially affected by lifestyle and somatic pathologies. Major peripheral disease, including trauma, sepsis, gastrointestinal disorders, kidney pathologies metabolic abnormalities and infections associated with systemic inflammation exacerbate the evolution of neurodegeneration [10-13]. Furthermore neurodegenerative disorders are linked to psychological stress, sleep disturbances, and to depression, all of which may accelerate the onset and evolution of neurodegeneration. The COVID-19 being generally manifested as a viral pneumonia with respiratory distress and prominent systemic inflammation is likely to modify the course of neurodegenerative pathologies. One common feature shared by neurodegeneration and COVID-19 is age: age is the major risk factor for neurodegenerative diseases [14], while old patients infected with SARS-Cov-2

(c) The Author(s). 2020 Open Access This article is licensed under a Creative Commons Attribution 4.0 International License, which permits use, sharing, adaptation, distribution and reproduction in any medium or format, as long as you give appropriate credit to the original author(s) and the source, provide a link to the Creative Commons licence, and indicate if changes were made. The images or other third party material in this article are included in the article's Creative Commons licence, unless indicated otherwise in a credit line to the material. If material is not included in the article's Creative Commons licence and your intended use is not permitted by statutory regulation or exceeds the permitted use, you will need to obtain permission directly from the copyright holder. To view a copy of this licence, visit http://creativecommons.org/licenses/by/4.0/. The Creative Commons Public Domain Dedication waiver (http://creativecommons.org/publicdomain/zero/1.0/) applies to the data made available in this article, unless otherwise stated in a credit line to the data. 
present the most severe clinical picture with prolonged course of the disease [15].

The neurological and psychiatric complications of COVID-19 are widely reported; these include encephalitis, cerebral infarction, delirium, depression, delirium, psychosis Guillain-Barré syndrome [16-20], MillerFisher syndrome, and etcetera $[19,21-28]$. In at least three cases the COVID-19 brought with it symptoms of clinical Parkinsonism demonstrating therefore a potential direct link between the SARS-CoV-2 infection and neurodegeneration (see [29] for details). These acute parkinsonian symptoms may be related to an acute damage to the dopaminergic system being thus distinct from sporadic classical Parkinson disease, and yet such association required serious consideration. How COVID-19 may affect the neurodegenerative process and what are the underlying mechanisms? Below we shall try to overview several possible scenarios (Fig. 1).

\section{(i) Direct infection of neural cells with SARS-Cov-2.}

The common way of the SARS-Cov-2 virus into the cell proceeds through binding of the RBD domain of the S-protein upon cleavage by furin to the receptor angiotensin-converting enzyme 2 (ACE2) with subsequent internalisation of the virus probably by endocytosis in either clathrin- or $\mathrm{pH}$-dependent manner, which may also involve endosomal proton pump and NAADPsensitive intracellular two-pore channel 2 [30-33]. The angiotensin system is operational in the nervous tissue and many cells of the brain including neurones and neuroglia express its components including ACE2 and furin [34-36]. In particular, ACE2 expressing neural cells are located in the brain stem, in the circumventricular organs (CVOs), the subfornical organ, paraventricular nucleus (PVN), nucleus of the tractus solitarius (NTS), and rostral ventrolateral medulla, all these structures having high vascularisation and physiologically leaky blood-brain barrier [37], which permits direct contact with blood-borne viral particles. An alternative pathways for SARS-CoV-2 entry into the brain through nasal epithelium with subsequent retrograde and trans-synaptic penetration through axons of olfactory neurones; this may bring the virus into the olfactory bulb $[38,39]$.

The virulence of SARS-CoV-2 may also involve neuropilin-1, known to bind furin-cleaved substrates [40, 41]. It appeared that spike coronavirus protein shows a polybasic Arg-Arg-Ala-Arg carboxyl-terminal sequence on the cleaved fragment of S1 that matches the predicted C-end rule (CendR) motif for physical interaction with neuropilins. The structure of neuropilin-1 has been resolved and the coordination of the extracellular domains 1-4 (a1a2b1b2) is shown in Fig. 2 [42]. It tunes out that the domain $\mathrm{B} 1$ is able to bind the small inhibitor molecule EG00229 [43], which suppresses the infectivity of SARS-CoV-2 [41]. Similarly, monoclonal antibody against neuropilin-1 significantly reduces viral

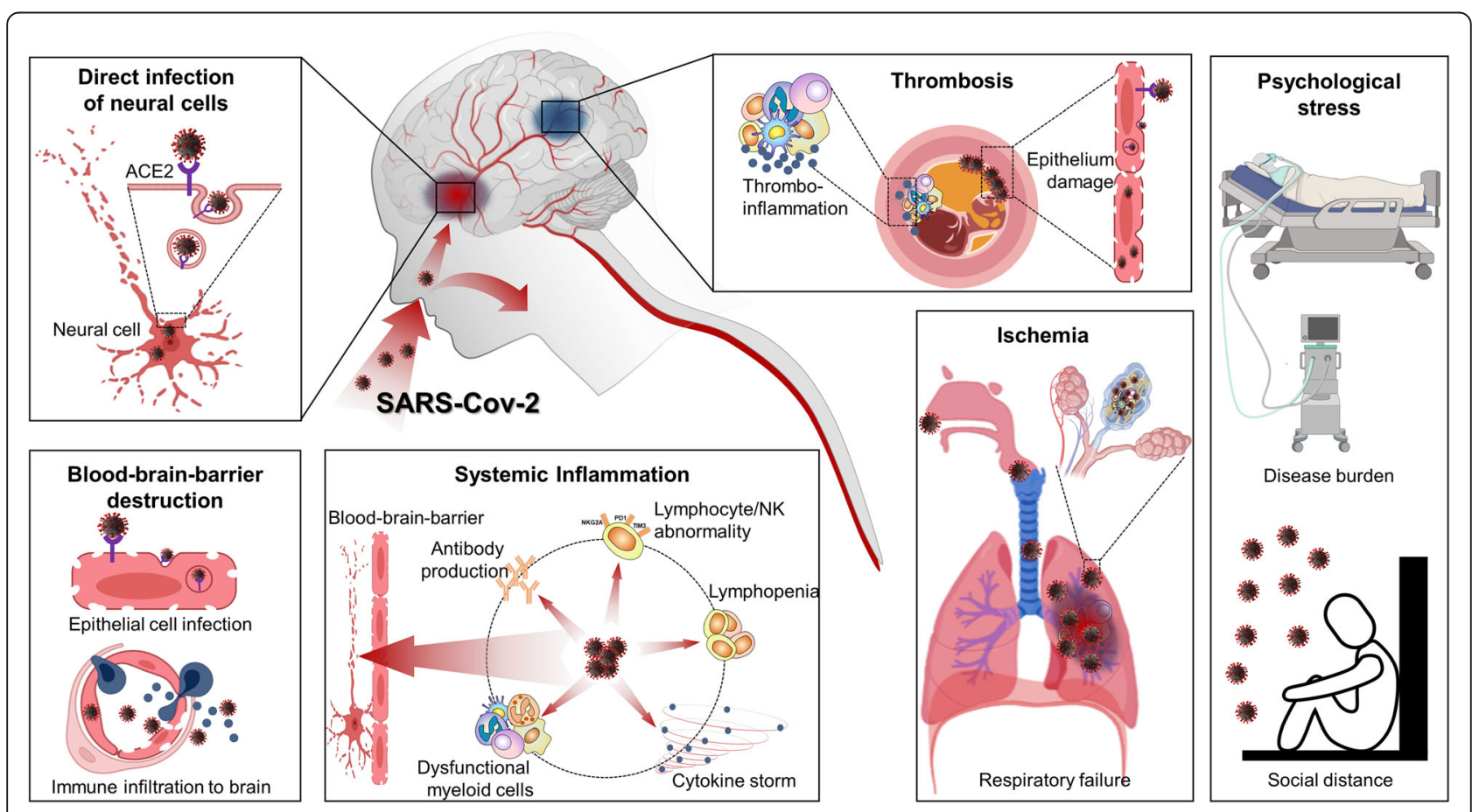

Fig. 1 COVID-19 damages the brain: possible links to neurodegeneration. See text for explanations and details 



Fig. 2 Structural constrains of neuropilin-1. a. Secondary structure of the extracellular domains 1-4 (a1a2b1b2) of mouse Neuropilin-1, PDB assignment 4GZ9 (DOI: https://doi.org/10.2210/pdb4GZ9/pdb) [42]. a'- $\beta$-D-mannopyranose-(1-4)-2-acetamido-2-deoxy- $\beta$-D-glucopyranose-(1-4)2-acetamido-2-deoxy-beta-Dglucopyranose. a" = 1,2-ethanediol. b. Surface structure of neuropilin-1 shown by hydrophobicity (same source of panel A). c. Binding of the small inhibitor molecule EG00229 on the B1 domain of human neuropilin-1. PDB assignment 3197 (DOI: https://doi.org/10.2210/pdb3197/pdb) [43]

infectivity [40]. In the latter case, post-mortem autopsies of the olfactory neuronal detected neuropilin-1 at the entry site for the virus. These data offer a significant potential intervention pathway for the treatment of the infection, including its involvement of the central nervous system [44]. Prediction of clinical outcome is essential for medical practice [45-53]; unfortunately, pathobiology of COVID-19 is still missing identifiable molecular determinants of disease progression and clinical outcome.

Infection of neurones and neuroglial cells have been documented in vitro, in particular in 2D cultures and brain organoids derived from human stem cells [54-57]. The viral particles have been also found in the postmortem brain tissues obtained from COVID-19 victims; the viral load was found in $30-50 \%$ of all specimens [58, 59]. Can these viruses damage neural cells beyond repair and instigate neurodegenerative process? This is difficult to assess at the moment; it is known that influenza can be associated (rarely) with encephalitis leading to a substantial damage to the brain tissue [60]. This damage has been detected at the cellular level; in particular such damage was manifested by clasmatodenrosis, indicative of severe degeneration of astrocytes [61]. Hitherto, such pronounced degenerative change in the SARS-CoV-2 infected brains has not been characterised. In addition, the persistence of SARS-CoV-2 in the brain after viral clearance from the respiratory system and blood remains to be characterised.

\section{(ii) Systemic inflammation.}

The systemic inflammation is the main feature of severe cases of COVID-19; the "cytokine storm" reflecting massive increase of pro-inflammatory factors in the blood, is a singular feature of COVID-19 pathogenesis [62]. It should be noted that in severe COVID-19 patients, $\mathrm{T}$ cells are often lost and the inflammation is characterized by innate immune responses [63]. How innate cytokines affect the central nervous system in absence of adaptive cytokines is not clear. The link between systemic inflammation and neurological as well as neuropsychiatric diseases is universally acknowledged with both innate and adaptive immune responses affecting the brain [64-67]. Cytokines, chemokines or even activated blood-borne immune cells can enter the brain through subfornical organs; in addition cytokines can compromise the $\mathrm{BBB}$ thus opening an alternative entry route for pro-inflammatory agents [68]. Even at low intensity of systemic inflammation, invasion of proinflammatory factors initiates sickness behaviour, a wide-spread syndrome characterised by depressive-like 
behaviours, lack of appetite, general fatigue, abnormal sleep patterns and decreased cognitive agility $[69,70]$. Conceptually sickness behaviour can be regarded as systemic defensive response aimed at conserving energetic responses for fighting the infection. Nonetheless, the immunological pathways activated during sickness behaviour are potentially damaging being linked to pathogenesis of major depression and neurodegeneration [71].

In sever cases systemic inflammation causes acute brain damage associated with psychiatric symptoms as well as with cognitive impairments indicative of neurodegeneration. In sepsis with bacteraemia, which is paramount example of severe systemic inflammation, almost $80 \%$ of patients develop sepsis-associated encephalopathy [72, 73] and sepsis-associated delirium [74, 75]. In the elderly, the sepsis associated encephalopathy often instigates severe cognitive impairments, both acute and long-lasting and exacerbates exiting neurodegenerative pathology $[68,76]$. Severe COBID-10 triggers systemic inflammation most likely on a comparable scale with sepsis [77], which thus may result in similar deleterious cognitive outcomes and is likely to aggravate existing neurodegenerative pathologies.

The first line of defence of the CNS against systemic inflammation and systemic infection is formed by astrocytes and microglia; both are participating towards glia limitans that provides parenchymal part of blood-brain barrier formed by astroglial endfeet and processes of juxtavascular microglia $[78,79]$. Systemic inflammation and associated disruption of BBB, which allows infiltration of various damage-associated molecular patterns into the nervous tissue, triggers reactive astrogliosis [80] and reactive microgliosis [81, 82]. Reactive gliosis is a powerful and evolutionary conserved defensive mechanism; suppression of gliotic response exacerbates neuropathologies including those triggered by infectious lesions [83, 84]. Both glial responses are present in the COVID-10 affected brains [85] with numerous documentations for areas of gliosis in COVID-19 post-mortem brains [86, 87]. At the same time systemic inflammation may damage glial cells, resulting in their atrophy and loss of functions; dystrophic astrocytes and microglia are known to facilitate initiation and pathological development of neurodegenerative disorders [88-91].

It has been also realised that COVID-19 patients with basic metabolic disorders such as type II diabetes are prone to develop severe inflammation. COVID-19 infection has been shown to cause hyperglycaemia, thus stimulating glycolysis [92] which, in turn, pushes macrophages to the pro-inflammatory phenotype [93], that may predispose patients to severe COVID-19 presentation with increased lethality. It remains unknown how long the hyperlycaemia last and how stable the pro- inflammatory macrophage maintain, although the longer the pro-inflammation persist, the more effect it will be on the development of neurodegeneration. Some COVID-19 patients maintain positive test for virus in stool months after viral negativity in the nose and in the throat [94]. Of note, the S-protein possesses a sequence similar to well known super-antigen staphylococcal enterotoxin B (SEB) [95]. This superantigen is linked to a persistent gut inflammation and impaired gut microbiota which represent another factor contributing to the development of neurodegenerative diseases.

\section{(iii) Autoimmunity in COVID-19 associated brain damage.}

Another brain-damaging mechanism, linked to systemic infection is associated with autoimmunity. Indeed autoimmune attack is known to cause encepahalopathies with neurological and psychotic symptoms [96-98]; and sometimes the acute psychosis is the leading symptoms, as, for example, in the case of anti- $\mathrm{N}$-methyl-D-aspartate (NMDA) receptor encephalitis [99, 100]. Viral infections have been shown to induce autoimmunity through, for example, a phenomenon known as molecular mimicry $[101,102]$. In the context of COVID-19 production of antiphospholipid autoantibodies has been detected [103] The brain being an immunoprivileged tissue protected by the BBB is particularly vulnerable for an autoimmune attack. The autoimmune damages to the CNS in particular may affect the white matter tracts and peripheral nerves [104]; the latter type of damage presented as a Guillain-Barré syndrome [17, 19], or its cranial variant Miller-Fisher syndrome [28] have both been reported in COVID-19 sufferers. Nonetheless such cases remain rare, and no autoantibodies have been ever identified in the cerebrospinal fluids of COVID-19 patients.

\section{(iv) Ischaemia .}

The main clinical presentation of COVID-19 is malignant pneumonia causing, even in mild cases, decrease in blood oxygenation; in severe cases omnipresent inflammation of lung tissue is associated with profound respiratory failure and severe hypoxia. Such global hypoxia inevitably affects the brain, the organ with highest demand for oxygen that is needed to sustain energyhungry nervous tissue. Cerebral hypoxia has multiple negative effects on the brain. The primary damage is associated with mounting of respiratory alkalosis and energy deprivation; decrease of arterial oxygen saturation below 75\% causes profound impairments of neuronal activity [105]. Hypoxia also causes oxidative damage to neural cells due to a rapid increase in production of reactive oxygen species, which swiftly overpower rather 
limited brain antioxidative defences [106]. Brain hypoxia is also directly linked to activation or exacerbation of inflammatory response by stimulating hypoxia inducible factors and the NF- $\mathrm{kB}$ signalling cascade, which in turn prompt the release of pro-inflammatory factors [107]. In summary, severe and/or prolonged hypoxia may cause widespread damage to brain structures being thus directly linked to neurodegeneration and cognitive deficits.

\section{(v) Thrombosis and stroke.}

The systemic inflammation accompanying COVID-19 increases blood levels of fibronectin, arguably through stimulating its liver synthesis [108]. Increased fibronectin facilitates clot formation and $20-50 \%$ of COVID patients demonstrate thrombotic and thromboembolic complications $[109,110]$. Among these complications stroke has been described relatively frequently with numbers varying between $1.6 \%$ and up to $20 \%$ of hospitalised patients [111-113], including people of young ages [114, 115]. The link between stroke and neurodegeneration is well documented. Stroke is associated with stroke-induced secondary neurodegeneration $[116,117]$ as well as with increased risk of Alzheimer's disease [118]. Covid-19 associated thrombosis therefore can be directly linked to neurodegenerative diseases.

\section{(vi) Psychological stress.}

Patients hospitalised with severe forms of COVID-19 are exposed to a prolonged and malignant stress associated with the gravity of their conditions, with extended period lung ventilation, with grave atmosphere of the intensive care unit and with periods of delirium, unconsciousness and, sometimes, coma. This aversive experience amounts to the trauma likely to induce the post-traumatic stress disorder, which is also linked to immune pathology $[119,120]$. In addition, maladaptive stress response (linked to powerful and long lasting stressors) exacerbates both systemic inflammation and inflammatory damage to the brain through activation of the hypothalamic-pituitary-adrenal axis with increase in gluocorticoids. Neuroinflammation is deeply associated with several neuropsychiatric and neuro-cognitive diseases, including depression, psychosis and neurodegeneration [121-124]. Previous analysis of SARS-Cov-1 infection revealed alarmingly high prevalence of neuropsychiatric sequalae with $40 \%$ of patients suffering from post-traumatic stress disorder and 36\% form depression in 50-80 months after their hospitalisation [125]. Psychological stress affects not only COVID-19 patients but also general population due to lockdown, self isolation and fear; these factors are especially prominent between old people. Depression is a well known risk factor of dementia and psychological burden of COVID-19 may increase the rate of neurodegenerative diseases in the aftermath of the pandemic [126].

\section{Recapitulation}

The pandemic of Coronavirus Disease 2019 (COVID-19) presents the world with the medical challenge associated with multifactorial nature of this pathology. COVID-19 affects the brain in many ways; often the COVID-19 is manifested by neurological and neuropsychiatric symptoms that include dizziness, disturbed sleep, cognitive deficits, delirium, hallucinations and depression. All these signal the damage to the nervous tissue which may substantially increase the incidence of neurodegenerative diseases and promote dementia.

\section{Acknowledgements}

The authors thank Eleonora Candi and Richard Knight for helpful and constructive criticisms

\section{Authors' contributions}

$\mathrm{AV}, \mathrm{GM}$ and $\mathrm{YS}$ conceived the project, $\mathrm{AV}, \mathrm{GM}, \mathrm{SM}, \mathrm{QL}$ and $\mathrm{YS}$ wrote the manuscript; QL prepared Fig. 1; GM prepared Fig. 2. All of the Authors have approved this submitted version.

\section{Funding}

This work has been supported by the Associazione Italiana per la Ricerca contro il Cancro (AIRC) to GM (IG\#20473; 2018-2022), Ministry of Health \& MAECI Italy-China Science and Technology Cooperation (\#PGR00961) to GM. National Key R\&D Program of China (2018YFA0107500) to YS, Suzhou 2020 Emergency Innovation Funding on COVID-19 Infection to YS, and the National Natural Science Foundation of China (81530043, 81861138015, 31771581 and 81571612) to YS.

\section{Availability of data and materials}

Not applicable.

Ethics approval and consent to participate

Not applicable.

\section{Consent for publication}

Not applicable.

\section{Competing interests}

The Authors declare that they have no competing interests.

\section{Author details}

${ }^{1}$ Faculty of Biology, Medicine and Health, The University of Manchester, Manchester M13 9PT, UK. ${ }^{2}$ Achucarro Center for Neuroscience, IKERBASQUE, 48011 Bilbao, Spain. ${ }^{3}$ CAS Key Laboratory of Tissue Microenvironment and Tumor, Shanghai Institute of Nutrition and Health, Chinese Academy of Sciences, 320 Yueyang Road, Shanghai 200031, China. ${ }^{4}$ University of Rome Tor Vergata, via Cracovia 1, 00133 Rome, Italy. ${ }^{5}$ State Key Laboratory of Radiation Medicine and Protection, The First Affiliated Hospital of Soochow University, Institutes for Translational Medicine, Soochow University Medical College, Suzhou 215123, Jiangsu, China.

Received: 18 November 2020 Accepted: 19 November 2020 Published online: 27 November 2020

\section{References}

1. Chen J, Lu H, Melino G, Boccia S, Piacentini M, Ricciardi W, Wang Y, Shi Y, Zhu T. COVID-19 infection: the China and Italy perspectives. Cell Death Dis. 2020;11:438

2. Shi Y, Wang Y, Shao C, Huang J, Gan J, Huang X, Bucci E, Piacentini M, Ippolito G, Melino G. COVID-19 infection: the perspectives on immune responses. Cell Death Differ. 2020;27:1451-4. 
3. Sharma A, Kumar Sharma S, Shi Y, Bucci E, Carafoli E, Melino G, Bhattacherjee A, Das G. BCG vaccination policy and preventive chloroquine usage: do they have an impact on COVID-19 pandemic? Cell Death Dis. 2020;11:516.

4. Li X, Wang Y, Agostinis P, Rabson A, Melino G, Carafoli E, Shi Y, Sun E. Is hydroxychloroquine beneficial for COVID-19 patients? Cell Death Dis. 2020; 11:512.

5. Katzman R. Editorial: the prevalence and malignancy of Alzheimer disease. A major killer. Arch Neurol. 1976;33:217-8.

6. Mayeux R, Stern Y. Epidemiology of Alzheimer disease. Cold Spring Harb Perspect Med. 2012;2:a006239.

7. Collaborators GD. Global, regional, and national burden of Alzheimer's disease and other dementias, 1990-2016: a systematic analysis for the global burden of disease study 2016. The Lancet Neurol. 2019:18:88-106.

8. Tysnes OB, Storstein A. Epidemiology of Parkinson's disease. J Neura Transm (Vienna). 2017:124:901-5.

9. Association A. Alzheimer's disease facts and figures. Alzheimers Dement. 2020;16:391-460.

10. Giridharan W, Masud F, Petronilho F, Dal-Pizzol F, Barichello T. Infectioninduced systemic inflammation is a potential driver of Alzheimer's disease progression. Front Aging Neurosci. 2019;11:122.

11. Holmes C. Review: systemic inflammation and Alzheimer's disease. Neuropathol Appl Neurobiol. 2013;39:51-68.

12. Lim SL, Rodriguez-Ortiz CJ, Kitazawa M. Infection, systemic inflammation, and Alzheimer's disease. Microbes Infect. 2015;17:549-56.

13. Walker KA, Ficek BN, Westbrook R. Understanding the role of systemic inflammation in Alzheimer's disease. ACS Chem Neurosci. 2019;10:3340-2.

14. Hou Y, Dan X, Babbar M, Wei Y, Hasselbalch SG, Croteau DL, Bohr VA. Ageing as a risk factor for neurodegenerative disease. Nat Rev Neurol. 2019; 15:565-81.

15. Koff WC, Williams MA. Covid-19 and immunity in aging populations - a new research agenda. N Engl J Med. 2020;383:804-5.

16. Zhao H, Shen D, Zhou H, Liu J, Chen S. Guillain-Barre syndrome associated with SARS-CoV-2 infection: causality or coincidence? Lancet Neurol. 2020;19:383-4

17. Sedaghat Z, Karimi N. Guillain Barre syndrome associated with COVID-19 infection: a case report. J Clin Neurosci. 2020;76:233-5.

18. Padroni M, Mastrangelo V, Asioli GM, Pavolucci L, Abu-Rumeileh S, Piscaglia MG, Querzani P, Callegarini C, Foschi M. Guillain-Barre syndrome following COVID-19: new infection, old complication? J Neurol. 2020;267:1877-9.

19. Arnaud S, Budowski C, Ng Wing Tin S, Degos B. Post SARS-CoV-2 GuillainBarre syndrome. Clin Neurophysiol. 2020;131:1652-4.

20. Tiet MY, AlShaikh N. Guillain-Barre syndrome associated with COVID-19 infection: a case from the UK. BMJ Case Rep. 2020;13. E-pub head of print. https://doi.org/10.1136/bcr-2020-236536.

21. Ellul MA, Benjamin L, Singh B, Lant S, Michael BD, Easton A, Kneen R, Defres S, Sejvar J, Solomon T. Neurological associations of COVID-19. Lancet Neurol. 2020;19:767-83.

22. Wang Q, Xu R, Volkow ND. Increased risk of COVID-19 infection and mortality in people with mental disorders: analysis from electronic health records in the United States. World Psychiatry. 2020. E-pub ahead of print. https://doi.org/10.1002/wps.20806.

23. Steardo L Jr, Steardo L, Verkhratsky A. Psychiatric face of COVID-19. Transl Psychiatry. 2020;10:261

24. Steardo L, Steardo L Jr, Zorec R, Verkhratsky A. Neuroinfection may contribute to pathophysiology and clinical manifestations of COVID-19. Acta Physiol (Oxf). 2020;229:e13473.

25. Paterson RW, Brown RL, Benjamin L, Nortley R, Wiethoff S, Bharucha T, Jayaseelan DL, Kumar G, Raftopoulos RE, Zambreanu L, et al. The emerging spectrum of COVID-19 neurology: clinical, radiological and laboratory findings. Brain. 2020;143:3104-20.

26. Pergolizzi JV Jr, Raffa RB, Varrassi G, Magnusson P, LeQuang JA, Paladini A, Taylor R, Wollmuth C, Breve F, Chopra M, et al. Potential neurological manifestations of COVID-19: a narrative review. Postgrad Med. 2020. https:// doi.org/10.1080/00325481.2020.1837503.

27. Li Z, Liu T, Yang N, Han D, Mi X, Li Y, Liu K, Vuylsteke A, Xiang H, Guo X. Neurological manifestations of patients with COVID-19: potential routes of SARS-CoV-2 neuroinvasion from the periphery to the brain. Front Med. 2020:14:533-41.
28. Gutierrez-Ortiz C, Mendez A, Rodrigo-Rey S, San Pedro-Murillo E, Bermejo-Guerrero L, Gordo-Manas R, de Aragon-Gomez F, Benito-Leon J. Miller fisher syndrome and polyneuritis cranialis in COVID-19. Neurology. 2020;95:e601-5.

29. Brundin P, Nath A, Beckham JD. Is COVID-19 a perfect storm for Parkinson's disease? Trends Neurosci. 2020. E-pub ahead of print. https://doi.org/10. 1016/j.tins.2020.10.009.

30. Bayati A, Kumar R, Francis V, McPherson PS. SARS-CoV-2 uses clathrinmediated endocytosis to gain access into cells. BioRxiv. 2020; preprint. https://doi.org/10.1101/2020.07.13.201509.

31. Wang H, Yang P, Liu K, Guo F, Zhang Y, Zhang G, Jiang C. SARS coronavirus entry into host cells through a novel clathrin- and caveolae-independent endocytic pathway. Cell Res. 2008;18:290-301.

32. Inoue $Y$, Tanaka N, Tanaka Y, Inoue S, Morita K, Zhuang M, Hattori T, Sugamura K. Clathrin-dependent entry of severe acute respiratory syndrome coronavirus into target cells expressing ACE2 with the cytoplasmic tail deleted. J Virol. 2007:81:8722-9.

33. Petersen $\mathrm{OH}$, Gerasimenko OV, Gerasimenko JV. Endocytic uptake of SARSCoV-2: the critical roles of $\mathrm{pH}, \mathrm{Ca}^{2+}$, and NAADP Function. 2020;1:zqaa003. https://academic.oup.com/function.

34. Gowrisankar $\mathrm{W}$, Clark MA. Angiotensin II regulation of angiotensinconverting enzymes in spontaneously hypertensive rat primary astrocyte cultures. J Neurochem. 2016;138:74-85.

35. Nemoto W, Yamagata R, Nakagawasai O, Nakagawa K, Hung WY, Fujita M, Tadano T, Tan-No K. Effect of spinal angiotensin-converting enzyme 2 activation on the formalin-induced nociceptive response in mice. Eur J Pharmacol. 2020;872:172950

36. Xia H, Lazartigues E. Angiotensin-converting enzyme 2: central regulator for cardiovascular function. Curr Hypertens Rep. 2010;12:170-5.

37. Duvernoy HM, Risold PY. The circumventricular organs: an atlas of comparative anatomy and vascularization. Brain Res Rev. 2007;56:119-47.

38. Netland J, Meyerholz DK, Moore S, Cassell M, Perlman S. Severe acute respiratory syndrome coronavirus infection causes neuronal death in the absence of encephalitis in mice transgenic for human ACE2. J Virol. 2008:82:7264-75.

39. Li K, Wohlford-Lenane C, Perlman S, Zhao J, Jewell AK, Reznikov LR, Gibson-Corley KN, Meyerholz DK, McCray PB Jr. Middle East respiratory syndrome coronavirus causes multiple organ damage and lethal disease in mice transgenic for human Dipeptidyl peptidase 4. J Infect Dis. 2016 213:712-22.

40. Cantuti-Castelvetri L, Ojha R, Pedro LD, Djannatian M, Franz J, Kuivanen S, van der Meer F, Kallio K, Kaya T, Anastasina M, et al. Neuropilin-1 facilitates SARS-CoV-2 cell entry and infectivity. Science. 2020;370:856-60.

41. Daly JL, Simonetti B, Klein K, Chen KE, Williamson MK, Anton-Plagaro C, Shoemark DK, Simon-Gracia L, Bauer M, Hollandi R, et al. Neuropilin-1 is a host factor for SARS-CoV-2 infection. Science. 2020;370:861-5.

42. Janssen BJ, Malinauskas T, Weir GA, Cader MZ, Siebold C, Jones EY. Neuropilins lock secreted semaphorins onto plexins in a ternary signaling complex. Nat Struct Mol Biol. 2012:19:1293-9.

43. Jarvis A, Allerston CK, Jia H, Herzog B, Garza-Garcia A, Winfield N, Ellard K, Aqil R, Lynch R, Chapman C, et al. Small molecule inhibitors of the neuropilin-1 vascular endothelial growth factor a (VEGF-A) interaction. J Med Chem. 2010:53:2215-26.

44. Davies J, Randeva HS, Chatha K, Hall M, Spandidos DA, Karteris E, Kyrou I. Neuropilin1 as a new potential SARSCoV2 infection mediator implicated in the neurologic features and central nervous system involvement of COVID19. Mol Med Rep. 2020;22:4221-6.

45. Jayashree S, Murugavel P, Sowdhamini R, Srinivasan N. Interface residues of transient protein-protein complexes have extensive intra-protein interactions apart from inter-protein interactions. Biol Direct. 2019;14:1.

46. Dobon B, Montanucci L, Pereto J, Bertranpetit J, Laayouni H. Gene connectivity and enzyme evolution in the human metabolic network. Biol Direct. 2019;14:17

47. Han Y, Ye X, Cheng J, Zhang S, Feng W, Han Z, Zhang J, Huang K. Integrative analysis based on survival associated co-expression gene modules for predicting neuroblastoma patients' survival time. Biol Direct. 2019;14:4

48. Han Y, Ye X, Wang C, Liu Y, Zhang S, Feng W, Huang K, Zhang J. Integration of molecular features with clinical information for predicting outcomes for neuroblastoma patients. Biol Direct. 2019;14:16. 
49. Kim SY, Jeong HH, Kim J, Moon JH, Sohn KA. Robust pathway-based multiomics data integration using directed random walks for survival prediction in multiple cancer studies. Biol Direct. 2019;14:8.

50. Baali I, Acar DAE, Aderinwale TW, HafezQorani S, Kazan H. Predicting clinical outcomes in neuroblastoma with genomic data integration. Biol Direct. 2018;13:20.

51. Polewko-Klim A, Lesinski W, Mnich K, Piliszek R, Rudnicki WR. Integration of multiple types of genetic markers for neuroblastoma may contribute to improved prediction of the overall survival. Biol Direct. 2018;13:17.

52. Suo C, Deng W, Vu TN, Li M, Shi L, Pawitan Y. Accumulation of potential driver genes with genomic alterations predicts survival of high-risk neuroblastoma patients. Biol Direct. 2018;13:14.

53. Mihaylov I, Kandula M, Krachunov M, Vassilev D. A novel framework for horizontal and vertical data integration in cancer studies with application to survival time prediction models. Biol Direct. 2019;14:22.

54. Song E, Zhang C, Benjamin Israelow B, Lu-Culligan A, Prado AV, Skriabine S, Lu P, Weizman O, Liu F, Dai Y, et al. Neuroinvasion of SARS-CoV- 2 in human and mouse brain. BioRxiv. 2020; Preprint. https://doi.org/10.1101/ 2020.06.25.169946

55. Zhang BZ, Chu H, Han S, Shuai H, Deng J, Hu YF, Gong HR, Lee AC, Zou Z, Yau T, et al. SARS-CoV-2 infects human neural progenitor cells and brain organoids. Cell Res. 2020;30:928-31.

56. Yi SA, Nam KH, Yun J, Gim D, Joe D, Kim YH, Kim HJ, Han JW, Lee J. Infection of brain Organoids and 2D cortical neurons with SARS-CoV-2 Pseudovirus. Viruses. 2020;12. E-pub ahead of print. https://doi.org/10.3390/ v12091004.

57. Ramani A, Muller L, Ostermann PN, Gabriel E, Abida-Islam P, MullerSchiffmann A, Mariappan A, Goureau O, Gruell H, Walker A, et al. SARSCoV-2 targets neurons of 3D human brain organoids. EMBO J. 2020;39: e106230.

58. Puelles VG, Lutgehetmann M, Lindenmeyer MT, Sperhake JP, Wong MN, Allweiss L, Chilla S, Heinemann A, Wanner N, Liu S, et al. Multiorgan and renal tropism of SARS-CoV-2. N Engl J Med. 2020;383:590-2.

59. Matschke J, Lutgehetmann M, Hagel C, Sperhake JP, Schroder AS, Edler C, Mushumba H, Fitzek A, Allweiss L, Dandri M, et al. Neuropathology of patients with COVID-19 in Germany: a post-mortem case series. Lancet Neurol. 2020;19:919-29.

60. Hayase $Y$, Tobita K. Influenza virus and neurological diseases. Psychiatry Clin Neurosci. 1997;51:181-4

61. Tachibana M, Mohri I, Hirata I, Kuwada A, Kimura-Ohba S, Kagitani-Shimono K, Fushimi H, Inoue T, Shiomi M, Kakuta Y, et al. Clasmatodendrosis is associated with dendritic spines and does not represent autophagic astrocyte death in influenza-associated encephalopathy. Brain and Development. 2019;41:85-95.

62. Coperchini F, Chiovato L, Croce L, Magri F, Rotondi M. The cytokine storm in COVID-19: an overview of the involvement of the chemokine/chemokinereceptor system. Cytokine Growth Factor Rev. 2020;53:25-32.

63. Tan L, Wang Q, Zhang D, Ding J, Huang Q, Tang YQ, Wang Q, Miao H. Lymphopenia predicts disease severity of COVID-19: a descriptive and predictive study. Signal Transduct Target Ther. 2020;5:33.

64. Schwartz M, Deczkowska A. Neurological disease as a failure of brainimmune crosstalk: the multiple faces of Neuroinflammation. Trends Immunol. 2016;37:668-79.

65. Carson MJ, Doose JM, Melchior B, Schmid CD, Ploix CC. CNS immune privilege: hiding in plain sight. Immunol Rev. 2006:213:48-65.

66. Hickey WF, Hsu BL, Kimura H. T-lymphocyte entry into the central nervous system. J Neurosci Res. 1991;28:254-60.

67. Varatharaj A, Galea I. The blood-brain barrier in systemic inflammation. Brain Behav Immun. 2017:60:1-12.

68. Sankowski R, Mader S, Valdes-Ferrer SI. Systemic inflammation and the brain: novel roles of genetic, molecular, and environmental cues as drivers of neurodegeneration. Front Cell Neurosci. 2015;9:28.

69. Capuron L, Lamarque D, Dantzer R, Goodall G. Attentional and mnemonic deficits associated with infectious disease in humans. Psychol Med. 1999;29:291-7.

70. Dantzer R. Cytokine, sickness behavior, and depression. Immunol Allergy Clin N Am. 2009;29:247-64

71. Maes M, Berk M, Goehler L, Song C, Anderson G, Galecki P, Leonard B. Depression and sickness behavior are Janus-faced responses to shared inflammatory pathways. BMC Med. 2012;10:66.
72. Shulyatnikova T, Verkhratsky A. Astroglia in Sepsis associated encephalopathy. Neurochem Res. 2020;45:83-99.

73. Ren C, Yao RQ, Zhang H, Feng YW, Yao YM. Sepsis-associated encephalopathy: a vicious cycle of immunosuppression. J Neuroinflammation. 2020;17:14.

74. Ely EW, Shintani A, Truman B, Speroff T, Gordon SM, Harrell FE Jr, Inouye SK, Bernard GR, Dittus RS. Delirium as a predictor of mortality in mechanically ventilated patients in the intensive care unit. JAMA. 2004;291:1753-62.

75. Ebersoldt M, Sharshar T, Annane D. Sepsis-associated delirium. Intensive Care Med. 2007;33:941-50.

76. Iwashyna TJ, Ely EW, Smith DM, Langa KM. Long-term cognitive impairment and functional disability among survivors of severe sepsis. JAMA. 2010;304: 1787-94.

77. Garcia LF. Immune response, inflammation, and the clinical Spectrum of COVID-19. Front Immunol. 2020:11:1441.

78. Joost E, Jordao MJC, Mages B, Prinz M, Bechmann I, Krueger M. Microglia contribute to the glia limitans around arteries, capillaries and veins under physiological conditions, in a model of neuroinflammation and in human brain tissue. Brain Struct Funct. 2019;224:1301-14.

79. Verkhratsky A, Nedergaard M. Physiology of Astroglia. Physiol Rev. 2018;98 239-389.

80. Verkhratsky A, Zorec R, Parpura V. Stratification of astrocytes in healthy and diseased brain. Brain Pathol. 2017:27:629-44.

81. Sierra A, Beccari S, Diaz-Aparicio I, Encinas JM, Comeau S, Tremblay ME. Surveillance, phagocytosis, and inflammation: how never-resting microglia influence adult hippocampal neurogenesis. Neural Plast. 2014;2014:610343.

82. Kettenmann H, Hanisch UK, Noda M, Verkhratsky A. Physiology of microglia. Physiol Rev. 2011;91:461-553.

83. Zorec R, Zupanc TA, Verkhratsky A. Astrogliopathology in the infectious insults of the brain. Neurosci Lett. 2019;689:56-62.

84. Pekny M, Pekna M, Messing A, Steinhauser C, Lee JM, Parpura V, Hol EM, Sofroniew MV, Verkhratsky A. Astrocytes: a central element in neurological diseases. Acta Neuropathol. 2016;131:323-45.

85. Tremblay M-E, Madore C, Bordeleau M, Tian L, Verkhratsky A. Neuropathobiology of COVID-19: the role for glia. Front Cell Neurosci. 2020; 14:a592214

86. Kanberg N, Ashton NJ, Andersson LM, Yilmaz A, Lindh M, Nilsson S, Price RW, Blennow K, Zetterberg H, Gisslen M. Neurochemical evidence of astrocytic and neuronal injury commonly found in COVID-19. Neurology. 2020; E-pub ahead of print. https://doi.org/10.1212/WNL.0000000000010111.

87. Reichard RR, Kashani KB, Boire NA, Constantopoulos E, Guo Y, Lucchinetti CF. Neuropathology of COVID-19: a spectrum of vascular and acute disseminated encephalomyelitis (ADEM)-like pathology. Acta Neuropathol. 2020;140:1-6.

88. Streit WJ, Sammons NW, Kuhns AJ, Sparks DL. Dystrophic microglia in the aging human brain. Glia. 2004;45:208-12.

89. Streit WJ, Xue QS, Tischer J, Bechmann I. Microglial pathology. Acta Neuropathol Commun. 2014;2:142.

90. Verkhratsky A, Rodrigues JJ, Pivoriunas A, Zorec R, Semyanov A. Astroglial atrophy in Alzheimer's disease. Pflugers Arch. 2019;471:1247-61.

91. Verkhratsky A, Marutle A, Rodriguez-Arellano JJ, Nordberg A. Glial asthenia and functional paralysis: a new perspective on Neurodegeneration and Alzheimer's disease. Neuroscientist. 2015:21:552-68.

92. Han J, Zhang L, Guo H, Wysham WZ, Roque DR, Willson AK, Sheng X, Zhou C, Bae-Jump VL. Glucose promotes cell proliferation, glucose uptake and invasion in endometrial cancer cells via AMPK/mTOR/S6 and MAPK signaling. Gynecol Oncol. 2015;138:668-75.

93. Du L, Lin L, Li Q, Liu K, Huang Y, Wang X, Cao K, Chen X, Cao W, Li F, et al. IGF-2 preprograms maturing macrophages to acquire oxidative phosphorylation-dependent anti-inflammatory properties. Cell Metab. 2019; 29:1363-75 e1368.

94. Xu Y, Li X, Zhu B, Liang H, Fang C, Gong Y, Guo Q, Sun X, Zhao D, Shen J, et al. Characteristics of pediatric SARS-CoV-2 infection and potential evidence for persistent fecal viral shedding. Nat Med. 2020;26:502-5.

95. Cheng MH, Zhang S, Porritt RA, Noval Rivas M, Paschold L, Willscher E, Binder M, Arditi M, Bahar I. Superantigenic character of an insert unique to SARS-CoV-2 spike supported by skewed TCR repertoire in patients with hyperinflammation. Proc Natl Acad Sci U S A. 2020;117:25254-62.

96. Crisp SJ, Kullmann DM, Vincent A. Autoimmune synaptopathies. Nat Rev Neurosci. 2016:17:103-17. 
97. Pollak TA, Lennox BR, Muller S, Benros ME, Pruss H, Tebartz van Elst L, Klein H, Steiner J, Frodl T, Bogerts B, et al. Autoimmune psychosis: an international consensus on an approach to the diagnosis and management of psychosis of suspected autoimmune origin. Lancet Psychiatry. 2020;7:93-108.

98. Kelley BP, Patel SC, Marin HL, Corrigan JJ, Mitsias PD, Griffith B. Autoimmune encephalitis: pathophysiology and imaging review of an overlooked diagnosis. AJNR Am J Neuroradiol. 2017;38:1070-8.

99. Kayser MS, Titulaer MJ, Gresa-Arribas N, Dalmau J. Frequency and characteristics of isolated psychiatric episodes in anti-N-methyl-d-aspartate receptor encephalitis. JAMA Neurol. 2013;70:1133-9.

100. Al-Diwani A, Handel A, Townsend L, Pollak T, Leite MI, Harrison PJ, Lennox BR, Okai D, Manohar SG, Irani SR. The psychopathology of NMDAR-antibody encephalitis in adults: a systematic review and phenotypic analysis of individual patient data. Lancet Psychiatry. 2019;6:235-46.

101. Lucchese G, Floel A. Molecular mimicry between SARS-CoV-2 and respiratory pacemaker neurons. Autoimmun Rev. 2020;19:102556.

102. Cappello F, Gammazza AM, Dieli F, de Macario EC, Macario AJ. Does SARSCoV-2 Trigger Stress-InducedAutoimmunity by Molecular Mimicry? A Hypothesis. J Clin Med. 2020;9:2038.

103. Zhang $Y$, Xiao M, Zhang S, Xia P, Cao W, Jiang W, Chen H, Ding X, Zhao H, Zhang $\mathrm{H}$, et al. Coagulopathy and Antiphospholipid antibodies in patients with Covid-19. N Engl J Med. 2020;382:e38.

104. Giovannoni G, Hartung HP. The immunopathogenesis of multiple sclerosis and Guillain-Barre syndrome. Curr Opin Neurol. 1996;9:165-77.

105. Goodall S, Twomey R, Amann M. Acute and chronic hypoxia: implications for cerebral function and exercise tolerance. Fatigue. 2014;2:73-92.

106. Zhao M, Zhu P, Fujino M, Zhuang J, Guo H, Sheikh I, Zhao L, Li XK. Oxidative stress in hypoxic-ischemic encephalopathy: molecular mechanisms and therapeutic strategies. Int J Mol Sci. 2016;17:2078.

107. Taylor CT, Doherty G, Fallon PG, Cummins EP. Hypoxia-dependent regulation of inflammatory pathways in immune cells. J Clin Invest. 2016;126:3716-24.

108. Wise J. Covid-19 and thrombosis: what do we know about the risks and treatment? BMJ. 2020;369:m2058.

109. Klok FA, Kruip M, van der Meer NJM, Arbous MS, Gommers D, Kant KM, Kaptein FHJ, van Paassen J, Stals MAM, Huisman MV, et al. Confirmation of the high cumulative incidence of thrombotic complications in critically ill ICU patients with COVID-19: an updated analysis. Thromb Res. 2020;191:148-50.

110. Middeldorp S, Coppens M, van Haaps TF, Foppen M, Vlaar AP, Muller MCA Bouman CCS, Beenen LFM, Kootte RS, Heijmans J, et al. Incidence of venous thromboembolism in hospitalized patients with COVID-19. J Thromb Haemost. 2020;18:1995-2002

111. Merkler AE, Parikh NS, Mir S, Gupta A, Kamel H, Lin E, Lantos J, Schenck EJ, Goyal P, Bruce SS, et al. Risk of ischemic stroke in patients with coronavirus disease 2019 (COVID-19) vs patients with influenza. JAMA Neurol. 2020. Epub ahead of print. https://doi.org/10.1001/jamaneurol.2020.2730.

112. Spence JD, de Freitas GR, Pettigrew LC, Ay H, Liebeskind DS, Kase CS, Del Brutto $\mathrm{OH}$, Hankey GJ, Venketasubramanian N. Mechanisms of stroke in COVID-19. Cerebrovasc Dis. 2020;49:451-8.

113. Helms J, Kremer S, Merdji H, Clere-Jehl R, Schenck M, Kummerlen C, Collange O, Boulay C, Fafi-Kremer S, Ohana M, et al. Neurologic features in severe SARS-CoV-2 infection. N Engl J Med. 2020;382:2268-70.

114. Oxley TJ, Mocco J, Majidi S, Kellner CP, Shoirah H, Singh IP, De Leacy RA, Shigematsu T, Ladner TR, Yaeger KA, et al. Large-vessel stroke as a presenting feature of Covid-19 in the young. N Engl J Med. 2020;382:e60.

115. Fifi JT, Mocco J. COVID-19 related stroke in young individuals. Lancet Neurol. 2020;19:713-5.

116. Ong LK, Walker RH, Nilsson M. Is stroke a neurodegenerative condition? A critical review of secondary Neurodegeneration and amyloid- $\beta$ accumulation after stroke. AIMS Medical Science. 2017:4:1-16..

117. Zhang J, Zhang Y, Xing S, Liang Z, Zeng J. Secondary neurodegeneration in remote regions after focal cerebral infarction: a new target for stroke management? Stroke. 2012;43:1700-5.

118. Vijayan M, Reddy PH. Stroke, vascular dementia, and Alzheimer's disease: molecular links. J Alzheimers Dis. 2016:54:427-43.

119. Furtado M, Katzman MA. Neuroinflammatory pathways in anxiety, posttraumatic stress, and obsessive compulsive disorders. Psychiatry Res. 2015;229:37-48.

120. Yang JJ, Jiang W. Immune biomarkers alterations in post-traumatic stress disorder: a systematic review and meta-analysis. J Affect Disord. 2020;268:39-46.

121. Bright F, Werry EL, Dobson-Stone C, Piguet O, Ittner LM, Halliday GM, Hodges JR, Kiernan MC, Loy CT, Kassiou M, et al. Neuroinflammation in frontotemporal dementia. Nat Rev Neurol. 2019;15:540-55.
122. Heppner FL, Ransohoff RM, Becher B. Immune attack: the role of inflammation in Alzheimer disease. Nat Rev Neurosci. 2015;16:358-72.

123. Bakunina N, Pariante CM, Zunszain PA. Immune mechanisms linked to depression via oxidative stress and neuroprogression. Immunology. 2015;144:365-73.

124. Marques TR, Ashok AH, Pillinger T, Veronese M, Turkheimer FE, Dazzan $P$, Sommer IEC, Howes OD. Neuroinflammation in schizophrenia: meta-analysis of in vivo microglial imaging studies. Psychol Med. 2019;49:2186-96.

125. Troyer EA, Kohn JN, Hong S. Are we facing a crashing wave of neuropsychiatric sequelae of COVID-19? Neuropsychiatric symptoms and potential immunologic mechanisms. Brain Behav Immun. 2020;87:34-9.

126. Ownby RL, Crocco E, Acevedo A, John V, Loewenstein D. Depression and risk for Alzheimer disease: systematic review, meta-analysis, and metaregression analysis. Arch Gen Psychiatry. 2006;63:530-8.

\section{Publisher's Note}

Springer Nature remains neutral with regard to jurisdictional claims in published maps and institutional affiliations.

Ready to submit your research? Choose BMC and benefit from:

- fast, convenient online submission

- thorough peer review by experienced researchers in your field

- rapid publication on acceptance

- support for research data, including large and complex data types

- gold Open Access which fosters wider collaboration and increased citations

- maximum visibility for your research: over $100 \mathrm{M}$ website views per year

At BMC, research is always in progress.

Learn more biomedcentral.com/submissions 